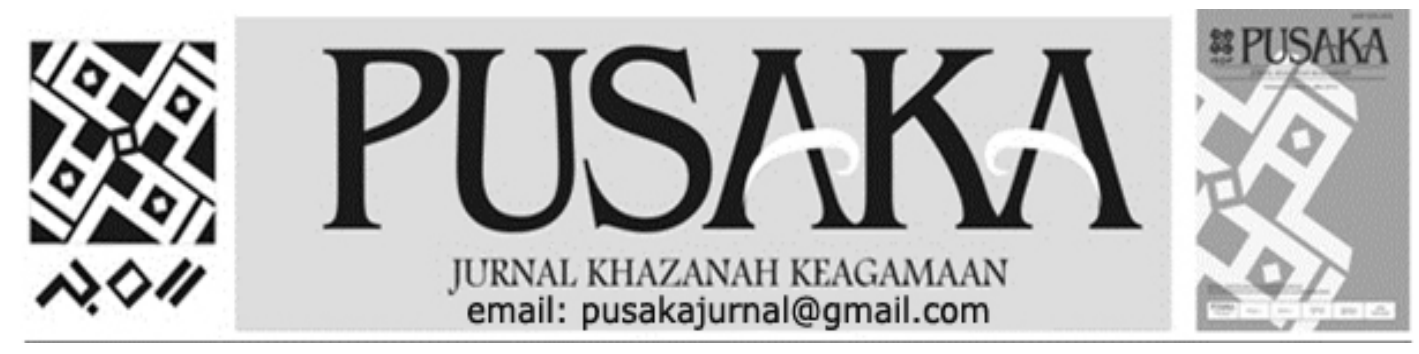

\title{
Pembinaan Kesiswaan Berbasis Sastra Religi Di Madrasah Aliyah Negeri 1 Palu
}

\author{
The Development of Students Based on Religious Literature \\ in Madrasah Aliyah Negeri 1 Palu
}

\author{
Abu Muslim \\ Balai Penelitian dan Pengembangan Agama Makassar \\ Jl. A.P. Pettarani No.72 Makassar. Telp: 0411-452952 \\ Email: abumuslim.litbang@gmail.com/hp.081343755509
}

\begin{tabular}{|c|c|}
\hline $\begin{array}{c}\text { Info } \\
\text { Artikel }\end{array}$ & Abstract \\
\hline $\begin{array}{l}\text { Diterima } \\
24 \\
\text { Januari } \\
2016\end{array}$ & $\begin{array}{l}\text { Penelitian yang bersifat deskriptif ini dilakukan dalam rangka penelusuran potensi } \\
\text { sastra religi siswa MAN } 1 \text { Palu. Lokus ini dipilih karena MAN } 1 \text { Palu sebagai } \\
\text { salah satu madrasah aliyah unggulan di Kota Palu, terlihat sangat prospektif dalam } \\
\text { potensi sastra religinya pembinaan kesastraan juga telah berjalan sejak lama. } \\
\text { Keterlibatan para siswa dalam segenap organisasi intra madrasah, turut membuat } \\
\text { pengembangan sastra ikut berjalan serta. Salah satu program kerja rutin yang } \\
\text { diagendakan adalah pembuatan majalah dinding dalam setiap momentum } \\
\text { memperingati hari-hari besar nasional atau hari-hari besar keagamaan Islam yang } \\
\text { bisa menjadi salah satu wadah dalam mewujudkan ekspresi literasi siswa madrasah } \\
\text { yang di dalamnya menghendaki penulisan dan atau pengutipan petuah-petuah } \\
\text { bijak, puisi, cerita pendek, dan lain-lain yang tentu sangat potensial menunjang } \\
\text { berkembangnya jiwa-jiwa berkesenian dan bersastra. Hal itu menunjukkan } \\
\text { kontekstualiasasi dan perluasan makna sastra religi yang tidak hanya berbasis }\end{array}$ \\
\hline $\begin{array}{l}\text { Revisi I } \\
\quad 8 \\
\text { Maret } \\
2017\end{array}$ & $\begin{array}{l}\text { Qurani, tetapi juga menghendaki eksplorasi mendalam tentang asimilasi aktif } \\
\text { antara sastra dalam gendre lokalitas diintegrasikan dengan sastra Islami. Hal ini } \\
\text { menunjukkan betapa dinamisnya perkembangan sastra yang ternyata juga sudah } \\
\text { menyasar dan tercerap oleh para siswa madrasah, yang diharapkan sebagai pioner } \\
\text { pengembangan sastra religi ke depan. } \\
\text { Kata kunci: Sastra Religi, Literasi Siswa, Pembinaan Kesiswaan }\end{array}$ \\
\hline $\begin{array}{l}\text { Disetujui } \\
\begin{array}{l}17 \\
\text { April } \\
2017\end{array}\end{array}$ & $\begin{array}{l}\text { This descriptive research is conducted in order to search the potential of religious } \\
\text { literature of MAN I Palu Students. Tihs fokus was because MAN I Palu as one of } \\
\text { the leading madrasah aliyah in Palu City, MAN I looks very prospective in its } \\
\text { religious literary potential. Literary coaching has also been in existence for a long } \\
\text { time. The involvement of students in all intra madrasah organizations, contributed } \\
\text { to the development of literature as well. One of the routine work programs } \\
\text { scheduled is the making of wall magazines in every moment to commemorate the } \\
\text { big days of national or religious big days of Islam that can be one of the containers } \\
\text { in realizing the expression of literacy of madrasah students in which desiring the } \\
\text { writing and I wisdom advice, poetry, short stories, and others that are very } \\
\text { potential to support the development of souls of art and literature. It shows the } \\
\text { contextualization and expansion of religious literary meaning not only based on } \\
\text { Quranic, but also requires an in-depth exploration of the active assimilation } \\
\text { between literature in locality gensre (read: regional literature) integrated with } \\
\text { Islamic literature. This shows how dynamic the development of literature that was } \\
\text { also already targeted and terirap by the madrasah students, which is expected as a } \\
\text { pioneer of religious literature development in the future } \\
\text { Keywords: eligious Literature, Literacy of Students, Student Development }\end{array}$ \\
\hline
\end{tabular}




\section{PENDAHULUAN}

Pembangunan generasi muda Indonesia yang berakhlak mulia dan berbudi pekerti luhur adalah citacita bangsa yang sebaiknya diprioritaskan. Demi mendukung optimalisasi pencapaian tujuan pendidikan kebangsaan, maka pengejewantahannya dapat diwujudkan dalam dimensi pengasahan potensi riligiusitas berbasis budaya. Dalam hal ini, pengembangan bakat kesastraan bisa digunakan sebagai media penyampaian pendidikan karakter kepada peserta didik. Dengan demikian, pembelajaran nilai-nilai karakter tidak hanya pada tataran kognitif saja, tetapi menyentuh pada internalisasi, dan pengamalan nyata dalam kehidupan peserta didik sehari-hari di masyarakat. Tentu saja, langkah visioner semacam ini tak akan banyak maknanya jika tidak diimbangi dan dukungan penuh dari berbagai kalangan secara intensif menginternalisasi pendidikan berbasis karakter dalam lingkungan keluarga dan masyarakat (Siswanti, 2012).

Peningkatan mutu pendidikan di sekolah tidak hanya terpaku pada pencapaian aspek akademik, melainkan juga aspek nonakademik, baik penyelenggaraannya dalam bentuk kegiatan kurikuler ataupun ekstrakurikuler, melalui berbagai program kegiatan yang sistematis dan sistemik. Dengan upaya seperti itu, peserta didik (siswa) diharapkan memperoleh pengalaman belajar yang utuh, hingga seluruh modalitas belajarnya berkembang secara optimal (Firdaus, 2009: 1).

$\mathrm{Di}$ dalam pembinaan kesiswaan, siswa diposisikan sebagai pusat utama dalam konsepsi persekolahan dan kesiswaan sekaligus juga menempati posisi strategis dalam administrasi pendidikan di sekolah. Program yang dilakukan dan dirancang sekolah, ujung-ujungnya untuk kepentingan siswa itu sendiri. Prestasi siswa akan menjadi ukuran keberhasilan program pendidikan di suatu sekolah. Namun walaupun kedudukan siswa begitu penting dan strategisnya, buku-buku literatur atau kajiankajian tentang kesiswaan dalam konsep manajemen pendidikan itu sendiri tidak terlalu banyak. dan sepertinya kurang mendapat perhatian lebih. Holmes \& Wynne mengungkapkan (dalam Anonim, 2009: 1 dalam Arini, 2012: h. 122134) berikut.

Books and university courses on educational administration do not give much direct attention to students, whose education is thejustification for the administrator's existence. The explanation is that, supposedly, everything educational administrators do is for and about pupils, directly indirectly. Therefore, by the account, addressing them separately isolates only afew factors of importance to them. The problem with mainstream approaches is that discussion of organizational theory and principal/teacher relation provides little evidence or argument to the effect that a particular approach will benefit students. Students are central in our conception of the school. 
Dengan demikian, dalam pembinaan kesiswaan terlingkup program kegiatan yang langsung melibatkan peserta didik (siswa) sebagai sasaran; ada pula program yang melibatkan guru sebagai mediasi atau sasaran antara (tidak langsung). Namun, sasaran akhir dari kinerja pembinaan kesiswaan adalah perkembangan siswa yang optimal; sesuai dengan karakteristik pribadi, tugas perkembangan, kebutuhan, bakat, minat, dan kreativitasnya.

Salah Satu aspek pembinaan kesiswaan yang kini mengemuka adalah dalam hal pembinaan Sastra. Selain fungsinya sebagai penunjang mata pelajaran yang lain, pengajaran sastra juga mempunyai fungsi ideologis, fungsi kultural, dan fungsi praktis (Sarwadi, 1971). Fungsi ideologis merupakan fungsi utama, yaitu sebagai salah satu sarana Pembina jiwa Pancasila. Fungsi kultural pengajaran sastra ialah memindahkan kebudayaan milik suatu generasi kepada generasi berikutnya. Sastra sebagai suatu materi kebudayaan diajarkan agar dapat dimiliki dan dikembangkan oleh generasi berikutnya. Oleh karena itu, pelaksanaan pengajaran sastra hendaknya tidak bersifat pasif verbalistis, akan tetapi dinamis kreatif. Fungsi praktis mencakup pengertian bahwa pengajaran sastra mempunyai fungsi membekali bahan-bahan yang mungkin berguna untuk melanjutkan studi ataupun bekal terjun di tengah kancah masyarakat.

"Tuhan memang tidak suka kepada penyair, kecuali orang yang bertakwa," kata HB Jassin, ketika melakukan wawancara dengan majalah Tempo, 13 Februari 1993, soal persinggungan sastra dan agama dalam perkembangan sastra Indonesia. HB Jassin menyiratkan bahwa sastra dan agama tidak harus selalu dihadapkan berlawanan. Tetapi saling mengisi ruang-ruang kosong masing-masing hingga mencapai derajat kesempurnaan sebagai manusia.

Kehadiran sastra religius dalam perkembangan kesusastraan Indonesia sebenarnya bukan fenomena yang baru lagi. Sekian tahun sebelum negeri ini merdeka, gejala semacam itu sudah mencuat. Haji Abdul Malik Karim Amrullah boleh dibilang sebagai assabiqunal awwalun yang menjadi pelopor dalam penulisan sastra religius. Karya-karya sastra religiusnya yang kemudian terkenal antara lain: Di Bawah Lindungan Ka'bah, Merantau Ke Deli dan Tenggelamnya Kapal Van der Wijck. Tidak semua sastrawan beragama mencerminkan jiwa keagamaan mereka dalam karyanya. Ada sementara sastrawan yang diketahui beragama (pasif), tulisan-tulisannya tidak memantulkan spirit keagamaan, malahan terkadang "mempermainkan" Tuhan dan agama dengan tak patut. Memang, suatu karya sastra yang berbicara tentang Tuhan dan agama bila tidak bertolak dari hati nurani dan imajinasi yang dipadukan dengan iman, dan sekadar perminan kata-kata, maka pada gilirannya akan melahirkan suatu karya sastra yang sinis bahkan apatis terhadap Tuhan dan agama. Jadi tidak dengan sendirinya sastrawan yang beragama membiaskan karangan dan tulisan yang religius, kecuali selain agama (dalam makna luas). Ia berusaha menanamkan nilainilai dan moral keagamaan di dalam 
setiap karyanya. Dengan demikian karya tersebut ada hubungannya dengan tanggung jawab hidupnya sebagai sastrawan dan hamba Tuhan.

Sebab, sebagaimana dikatakan pujangga Islam asal Pakistan Dr. Muhammad Iqbal, bahwa agama (baca: Islam) bukan soal sebagian-sebagian, melainkan justru menacakup seluruhs segi-segi kehidupan. Sebagai sastrawan muslim yang religius umpamanya, maka ia merasa bahwa tugas menulis/mengarang mesti dikaitkan dengan misi kehidupan insan beriman, yaitu ibadah. Hal ini dikarikaturiskan Allah dalam Alquran surah al-Zuriyyāt ayat 56: "Wamaa khalaqtul jinna wal insa illa liya'buduun; dan tidaklah Aku jadikan jin dan manusia melainkan untuk mengabdi (dengan penuh ketaataan) kepadaKu."

Maka ketika kita membaca cerpen "Rubuhnya Surau Kami"-nya AA Navis, "Ketika Isteriku Mengaji"-nya Asrul Rumbaya, "Pengakuan"-nya Eka Budianta, "Makam"-nya Zainuddin Tamir Koto, "Perjalanan Zikir"-nya Benni Setia, "Ziarah"-nya Sandi Firly, "Auzan"-nya Muhammad Radi, "Nyanyi Langgar Sunyi"-nya Muhammad Fuad Rahman, "Hitam Putih Kotaku"-nya Rismiyana, (sekadar menyebut sejumlah nama), pun saat kita membaca puisi "Lautan Jilbab"-nya Emha Ainun Nadjib, "Doa dari Seseorang yang Sangat Sulit Sekali untuk Berdoa"-nya Ajamudin Tifani, "Perarakan Senja"nya Bachtar Suryani, "Ritus Puisi"nya Burhanuddin Soebeli, "Membayangkan Baitullah" nya Eza Thabri Husano (kembali, sekadar menyebut sejumlah nama), kita akan dapat merasakan betapa sikap religiusitas para cerpenis dan penyair tersebut terhadap agama yang mereka anut.

Perasaan religius dan keindahan karya sastra seolah berjabat tangan untuk tumbuh subur dalam khazanah kesusastraan Indonesia. Sastra menjadi salah satu sarana untuk mengungkapkan perasaan religiusitas yang dialami oleh para sastrawan. Hamzah Fansuri, Bukhari Al-Jauhari, Nurudin Al-Raniri, Raja Ali Haji adalah beberapa penyair yang banyak menuliskan perasaan religius dalam karya-karyanya di masa kesusastraan Melayu Lama. Hingga masuk pada era Pujangga Baru, nama Amir Hamzah, Samadi, Rifa'i Ali, dan Ali Hamsyi patut dikedepankan dalam membicarakan karya sastra yang bernapaskan religiusitas. Karyakarya Sastra religi ini, makin mendapatkan tempat pada era 1960 dan 1970-an hingga menyebabkan polarisasi penulisan Sastra religi yang tidak hanya didominasi oleh sastrawan Islam saja. Sastrawan nonMuslim pun seperti Rendra (sebelum menjadi mualaf), Iwan Simatupang, JE Tatengkeng dan yang lainnya banyak juga menulis karya sastra yang bernapaskan religiusitas. Namun, seperti yang dikatakan oleh Teeuw, sastra non-Islam (khususnya Kristen) tidak banyak berkembang dalam sastra Indonesia modern. Hal ini disebabkan kebudayaan Indonesia umumnya tidak banyak dipengaruhi atau diresapi oleh kebudayaan Kristen, dibandingkan kesusastraan yang berkembang di Eropa (Teeuw, 1984: 119). Oleh karena itulah, perkembangan Sastra religi di Indonesia lebih banyak didominasi 
oleh karya-karya sastra yang bernapaskan religius Islam.

Hal inilah yang juga ditangkap oleh Balai Litbang Agama Makassar, yang dalam dua tahun terakhir ini telah melakukan project pengembangan softskills karya sastra religi dengan menjadikan siswa Madrasah Aliyah sebagai bagian integral pengembangan berbasis karya sastra religi. Terlihat dari dua tahun pelaksanaan, bahwa terdapat ragam pembinaan sastra religi di masing-masing madrasah sesuai dengan konteks daerahnya.

Bahkan jika dilihat lebih dalam melalui karya-karya yang dihasilkan, menunjukkan semangat yang sangat luar biasa dari para siswa madrasah Aliyah. Genre penulisan yang terlihat sudah mulai bagus dan sangat potensial untuk terus dikembangkan jika dilakuakan pembinaan yang berkesinambungan, begitu yang disampaikan oleh Ahmad Tohari ketika diminta pendapatnya tentang karya-karya sastra religi siswa MA yang telah dikumpulkan. Tinggal bagaimana pembinaan itu harus ditindaklanjuti berbasis Madrasah masing-masing melalui sistem terpadu dan pembentukan sanggar-sanggar sastra di berbagai madrasah dalam rangka menumbuhkembangkan Sastra religi di Madrasah Aliyah. Hal itu pula yang semakin membuat para peserta semakin terlecut semangatnya untuk berkarya, tentu dengan dukungan dari pihak Madrasah.

Dari semangat dan antusiasme peserta workshop itu kemudian menghadirkan semacam ide untuk pengembangan Sastra religi berbasis madrasah, dan untuk mewujudkan itu tentu harus terlebih dahulu dilakukan semacm pelacakan dalam bentuk penelitian dalam rangka membandingkan sistem pembinaan Sastra religi di masing-masing madrasah untuk selanjutnya dirumuskan rekomendasi pembuatan role model $/$ modul untuk pengembangan dan sistem pembelajaran sastra religi di madrasah. Oleh karena itu, penelitian ini kemudian digagas untuk memulai melihat dan melacak akar pembinaan sastra di madrasah Aliyah untuk diketengahkan dan dijadikan sebagai model perbandingan bagi madrasah lainnya dengan mengambil beberapa sampel pola pembinaan Sastra religi melalui pengajaran, dan kegiatankegiatan yang berhubungan dengan itu.

Berdasar pada latar belakang tersebut, maka dipandang perlu untuk melakukan penelitian lebih lanjut yang dirangkum dalam permasalahan pokok yakni Bagaimana Sistem Pembinaan Kesiswaan berbasis Sastra religi di Madrasah Aliayah?. Pokok masalah tersebut kemudian diturunkan pada beberapa pertanyaan penelitian sebagai berikut:

1. Bagaimana Potensi Sastra religi siswa Madrasah Aliyah Bersangkutan?

2. Bagaimana mekanisme pelaksanaan pembinaan kesiswaan berbasis Sastra religi di MA?

3. Bagaimana problem yang dihadapi dan strategi yang diupayakan oleh pendidik dan peserta didik dalam pembinaan dan pengembangan Sastra religi di MA?

Tujuan Penelitian ini adalah: 
1. Tujuan Umum: untuk mengetahui sistem pembinaan Sastra religi di MA.

2. Tujuan Khusus:

a. Mengetahui Potensi Sastra Religi siswa di Madrasah Aliyah.

b. Mengetahui mekanisme pelaksanaan pembinaan kesiswaan Sastra Religi di MA.

c. Mengetahui problem yang dihadapi dan strategi yang diupayakan MA dalam pengembangan Sastra Religi.

Kegunaan Penelitian ini adalah:

1. Menjadi bahan kebijakan bagi pemerintah.

2. Sebagai referensi akademik bagi penelitian selanjutnya, baik di dalam maupun di luar lingkungan Balai Litbang Agama Makassar.

Penelitian ini difokuskan

pada penelusuran terkait pembinaan kesiswaan di Madrasah Aliyah yang menitikberatkan pada pembinaan sastra religius, dengan terlebih dahulu mengidentifikasi potensi kesusatraan religi para siswa madrasah aliyah yang bisa dilacak melalui karya, keterlibatan dalam berbagai even, serta kreatifitas lainnya, selanjutnya melakukan pengamatan terhadap pelaksanaan pembinaan siswa berbasis sastra religius yang dilakukan oleh sekolah dan perangkatnya. Tahap akhir adalah melihat problem yang dihadapi dan strategi yang diupayakan MA dalam pembinaan dan pengembangan Sastra Religi.

Menurut kamus lengkap bahasa Indonesia (Badudu, 2002: 316) bahwa "pembinaan berarti usaha, tindakan dan kegiatan yang digunakan secara berdayaguna dan berhasil guna untuk memperoleh hasil yang baik". Dari definisi tersebut dapat disimpulkan bahwa pembinaan adalah suatu usaha dan kegiatan yang dilakukan untuk meningkatkan apa yang sudah ada kepada yang lebih baik (sempurna) baik terhadap yang sudah ada (yang sudah dimiliki). Dari penjelasan tersebut di atas, maka pembinaan yang di maksud adalah pembinaan kepribadian secara keseluruhan. Secara efektif dilakukan dengan memperhatikan sasaran yang akan dibina. Pembinaan dilakukan meliputi pembinaan moral, pembentukan sikap dan mental. Pembinaan mental merupakan salah satu cara untuk membentuk ahklak manusia agar memiliki pribadi yang bermoral, berbudi pekerti luhur dan bersusila, sehingga seseorang dapat terhindar dari sifat tercela sebagai langkah penanggulangan terhadap timbulnya kenakalan remaja. Mulyasa (2008:43) menjelaskan pembinaan kesiswaan adalah segala kegiatan yang meliputi perencanaan, pengawasan, penilaian,dan pemberian bantuan kepada siswa sebagai insan peribadi, insan pendidikan, insan pembangunan agar siswa tumbuh dan berkembang sebagai manusia seutuhnya dengan tujuan pendidikan nasional berdasarkan pancasila.

Sementara yang dimaksud dengan sastra religius dalam penelitian ini, dioperasionalkan melalui istilah Sastra Islam. Sastra Islam menurut Said Hawwa adalah seni atau sastra yang berlandaskan kepada akhlak Islam (Said Hawwa, 2004). Sedangkan menurut Ala al 
Mozayyen sastra Islam muncul sebagai media dakwah, yang di dalamnya terdapat tujuh karakteristik konsistensi, pesan, universal, tegas dan jelas, sesuai dengan realita, optimis, dan menyempurnakan akhlak manusia (Mozayyen, 2011). Menurut Abdurrahman Wahid, sastra Islam merupakan bagian dari peradaban Islam yang dapat dilihat dari dua sisi, pertama yaitu orang yang condong melihatnya secara legalitas formal dimana sastra Islam harus selalu bersandar pada Alquran dan Hadits sedangkan yang kedua orang yang condong melihat sastra Islam dari pengalaman religiusitas (keberagamaan) seorang muslim yang tidak bersifat formal legislatif, artinya sastra Islam tak harus bersumber dari Alquran dan Hadits (formal) dan bersifat adoptif terhadap pengaruh-pengaruh lain terutama dimensi sosiologis dan psikologis sastrawan muslim yang tercermin dari karyanya yang menggambarkan pengalaman keberagamaannya (Majalah Horison, 7/1984).

\section{Kajian Pustaka \\ Pembinaan Kesiswaan}

Di dalam Peraturan Menteri

Pendidikan Nasional Nomor 39 Tahun 2008 disebutkan ada empat tujuan pembinaan kesiswaan, yakni:

a. Mengembangkan potensi siswa secara optimal dan terpadu yang meliputi bakat, minat, dan kreativitas.

b. Memantapkan kepribadian siswa untuk mewujudkan ketahanan sekolah sebagai lingkungan pendidikan sehingga terhindar dari usaha dan pengaruh negatif dan bertentangan dengan tujuan pendidikan. c. Mengaktualisasikan potensi siswa dalam pencapaian prestasi unggulan sesuai bakat dan minat. Menyiapkan siswa agar menjadi warga masyarakat yang berakhlak mulia, demokratis.

d. Menghormati hak-hak asasi manusia dalam rangka mewujudkan masyarakat madani (civil society).

Pembinaan kesiswaan adalah upaya sekolah melalui kegiatankegiatan siswa di luar jam pelajaran di kelas untuk mengusahakan agar siswa dapat bertumbuh dan berkembang sebagai manusia seutuhnya sesuai dengan tujuan pendidikan nasional (Chaniago, 2010: 5). Kegiatan ini dilakukan disekolah atau di lingkungan masyarakat untuk menunjang program pengajaran (Nasir, 2007: 58). Secara rinci Pembinaan kesiswaan memiliki tujuh tujuan, yaitu: a) Meningkatkan peran serta dan membina sekolah sebagai wiyata mandala. b) Menumbuhkan daya tangkal siswa dari pengaruh negatif.

c) Memantapkan kegiatan ekstrakurikuler menunjang pencapaian kurikulum. d) Meningkatkan apresiasi dan penghayatan seni. e) Menumbuhkan sikap berbangsa dan bernegara. f) Meneruskan dan mengembangkan jiwa semangat serta nilai-nilai 45 , dan g) Meningkatkan kesegaran jasmani dan rohani. Dengan berpedoman pada tujuan dan maksud kegiatan pembinaan kesiswaan di sekolah dapat ditetapkan prinsipprinsip program ekstrakurikuler seperti yang diungkapkan oleh Suryosubroto (2007: 275) yaitu (1) semua murid, guru, dan personal 
administrasi hendaknya ikut serta dalam usaha meningkatkan program, (2) kerjasama dalam tim adalah fundamental, (3) pembatasanpembatasan untuk partisipasi hendaknya dihindarkan, (4) proses lebih penting daripada hasil, (5) program hendaknya lebih komprehensif dan seimbang dapat memenuhi kebutuhan dan minat semua siswa, (6) program hendaknya memperhitungkan kebutuhan khusus sekolah, (7) program harus dinilai berdasarkan sumbangannya kepada nilai-nilai pendidikan di sekolah dan efisiensi pelaksanaannya, (8) kegiatan ekstrakurikuler ini hendaknya menyediakan sumbersumber motivasi yang kaya bagi pengajaran kelas, sebaliknya pengajaran kelas hendaknya menyediakan sumber motivasi yang kaya bagi kegiatan murid, dan (9) kegiatan ekstrakurikuler ini hendaknya dipandang sebagai integral dari keseluruhan program pendidikan sekolah, tidak sekadar tambahan atau sebagai kegiatan yang berdiri sendiri.

Pendidikan pada umumnya merupakan suatu intervensi eksternal yang memungkinkan peserta didik mengembangkan bakat, minat, dan kemampuan dalam dirinya (intern) secara optimal sehingga berguna bagi diri, masyarakat dan bangsanya. Setiap manusia dilahirkan memiliki bakat dan kemampuan yang berbedabeda. Oleh karena itu, membutuhkan pendidikan yang berbeda pula.

King (2009) memuat beberapa model pembinaan kesiswaan untuk siswa berbakat dengan beberapa pendekatan, yaitu (1) loncat kelas (grade skipping), (2) percepatan penempatan individual atas beberapa mata pelajaran (advanced placement or accelerated pacing for individual subject areas), (3) masuk sekolah lebih awal (early entrance to school or collage), (4) pembelajaran beberapa program mata kuliah pada sekolah di atasnya (enrollment in college courses while still high school), dan (5) program belajar khusus seperti kelas musim panas dan sejenisnya (special fastpaced courses: classroom, summer, or correspondence). Untuk melakukan strategi pembinaan siswa berbasis bakat dan prestasi seorang guru perlu meciptakan suatu situasi pembelajaran yang banyak member kesempatan pada siswa untuk memecahkan masalah, melakukan beberapa percobaan, mengembangkan gagasan atau konsep-konsep siswa sendiri. Guru juga harus bersikap demokratis, terbuka, bersahabat, dan percaya kepada siswa (Sukmadinata, 2006: 105).

Kunjungan sekolah (school visit) merupakan strategi yang digunakan dalam bentuk kegiatan pemantauan (monitoring), penilaian (evaluasi), pengamatan (observasi), studi kasus, dan atau konsultasi klinis-pengembangan, baik tentang persiapan, pelaksanaan, maupun hasil suatu program pembinaan kesiswaan. Strategi kunjungan sekolah dilaksanakan terutama untuk mempersempit kesenjangan antara kebijakan yang dihasilkan di tingkat pusat dengan pelaksanaan suatu program pembinaan kesiswaan di tingkat sekolah sasaran (Senjaya, 2008: 10).

Perlombaan merupakan
strategi pelaksanaan program
pembinaan
kompetitif, melibatkan siswa atau


sekolah peserta secara langsung dalam suatu event atau kegiatan, baik yang bertaraf internasional maupun nasional. Strategi perlombaan dapat dilaksanakan sebagai kegiatan tunggal (bukan kegiatan yang dilaksanakan secara bertahap dari tingkat bawah); dapat pula (lazimnya) dilakukan secara bertahap dari tingkat sekolah, kecamatan, kabupaten/kota, provinsi, hingga tingkat nasional ataupun internasional (Senjaya, 2008: 11).

\section{Manajemen Pendidikan}

Sebagaimana layaknya sebuah lembaga pendidikan, sekolah sebagai sebuah sistem, seharusnya memiliki sebuah mekanisme yang mampu mengatur dan mengoptimalkan berbagai komponen dan sumber daya pendidikan yang ada. Dalam dunia pendidikan, hal ini disebut manajemen pendidikan. Depdiknas (2008: 76) membagi empat prinsip dasar manajemen kesiswaaan: 1) Siswa harus diperlakukan dengan subyek dan bukan obyek, sehingga harus didorong untuk berperan serta dalam setiap perencanaan dan pengambilan keputusan yang terkait dengan kegiatan mereka, 2) Kondisi siswa sangat beragam, ditinjau dari kondisi fisik, kemampuan intelektual, sosial ekonomi, minat, dan seterusnya. Oleh karena itu, diperlukan wahana kegiatan yang beragam, sehingga setiap siswa memiliki wahana untuk berkembang secara optimal, 3) Siswa hanya akan termotivasi belajar jika mereka menyenangi apa yang diajarkan, 4) Pengembangan potensi siswa tidak hanya menyangkut ranah kognitif, tetapi juga ranah afektif, dan psikomotor.

\section{Sastra Islami}

Dalam paradigma sastra Islam, konsep baku sastra dalam perspektif Islam belum disepakati secara menyeluruh. Belum matangnya paradigma sastra dalam perspektif Islam disebabkan karena adanya perdebatan dan kontroversi yang tidak pernah tuntas tentang sastra dalam dalam perspektif Islam. Perdebatan yang tidak pernah tuntas ini disebabkan oleh banyak faktor. Di antara faktor yang sangat menonjol adalah adanya beberapa ayat dan hadits Nabi yang ditafsirkan oleh sebagian besar ulama sebagai bukti tekstual kekurangsimpatikan Islam dengan apa yang disebut dengan seni sastra (Tohari, 1998:1). Pendapat semacam ini sebetulnya merupakan warisan dari kritikus sastra abad 2 dan $3 \mathrm{H}$, ketika mengatakan bahwa sastra menjadi lemah dan tidak berfungsi sejak Islam datang dan memposisikan diri sebagai musuh atas sastra (Abdurrahman, 1992:65). Pada masa sekarang arti sastra sudah dapat ditempatkan pada posisi yang proporsional. Di kalangan umat Islam sendiri sastra sudah dapat diterima kembali dan menjadi konsumsi sehari-hari untuk kehidupan dan keperluan dakwah.

Terlepas dari kontroversi dan perdebatan tentang sastra Islam di atas, fenomena kehadiran sastra Islam tidak dapat dihilangkan dari realitas kehidupan. Pada tahun 1960an seorang sastrawan Mesir Najib Kailany menggagas dan mencoba membangun sebuah konsep yang disebutnya dengan konsep sastra Islam. Ide ini dituangkannya dalam beberapa buah bukunya: alIslamiyah wa al-Mazahib alAdabiyah, al-Thariq Ila Ittihadin 
Islamiyyin, dan Haula al-Din wa alDaulah (Kaailani, 1985:5). Konsep ini meski mendapat banyak respon namun belum nampak kemajuan perkembangan pembahasannya. Respon yang cukup luas ini hanya sampai berwujud sebuah Muktamar Islam untuk al-Adab al-Islamy, muktamar yang pertama diadakan di India. Kedua di Universitas Madinah Saudi Arabia dan Ketiga di Universitas Imam Muhammad Ibnu Saud Riyad (Kaailani, 1985:6). Muktamar-muktamar ini melahirkan badan sastra Islam tingkat Internasional yang disebut dengan Rabithah al-Adab al-Islamy alAlamy yang diketuai oleh Ulama Besar India Syaikh Abu al-Hasan Ali al-Hasany al-Nadawy. Dan pada tahun 1994 menerbitkan Jurnal alAdab al-Islamy. Pada tahun-tahun belakangan ini di Indonesia mulai sering dibicarakan tentang sastra sufi dan kecenderungan sufistik dalam sastra Indonesia, khususnya sehubungan dengan apa yang dinamakan Angkatan 70 atau sastra 70-an. Angkatan 70 dalam sastra ini bukan saja menampakkan kecenderungan sufistik, namun beberapa tokoh utamanya seperti: Danarto, Sutarzy Calzoum Bachri, Kuntowijoyo, M.Fudoli Zaini, Sapardi Djoko Damono dll. mempelajari dengan serius tasawuf dengan kesusastraannya, malahan menerjemahkan pula karya-karya para penyair sufi. Dengan beberapa penyair dan seniman lain seperti Taufiq Ismail, Amak Baljun, Chairul Umam, Ikranegara, Hamid Jabbar, Putu Wijaya dll. Bahkan telah tampil dalam acara pembacaan khusus sajak-sajak penyair sufi yang diselenggarakan oleh Dewan
Kesenian Jakarta di Taman Ismail Marzuki pada tahun-tahun 1982, 1983 dan 1984, seperti Malam Rumi, Malam Hamzah Fansuri dan Peringatan Iqbal (Hadi, 1985:v).

Belakangan Abdul Hadi WM. menulis tanggapan balik atas tulisan Simuh dengan judul "Menjawab Persoalan Sastra Islam". Menurutnya cakrawala sastra Islam sudah tentu sama luasnya dengan ajaran Islam itu sendiri. Karena itu, dalam memandang seni dan sastra Islam kita mesti bertolak dari dalam seni dan sastra Islam itu sendiri bukan dari arah luar sastra Islam. Dimensi tauhid sastra Islam yang ia maksudkan tidak melulu hanya berasyik-masyuk dengan Tuhan, tapi juga mencakup tanggung jawab sosial. Karena telah diakui bahwa tradisi sastra Islam tidak dapat dipisahkan dari perkembangan tradisi intelektual dan spiritualitasnya.

Para sastrawan yang beriman menghasilkan karya-karya yang mengandung nilai-nilai keislaman dan tentu saja menghindari unsurunsur kekufuran atau kemaksiatan. Makna sastra islami adalah sastra yang menuju hidup berkeadaban. Dalam kenyataannya sastra islami bisa dipilah menjadi dua bagian. Pertama, sastra islami yang cocok buat para pelajar dan remaja. Sastra jenis ini disajikan dengan bahasa yang mudah, pemikiran yang sederhana sampai menengah dan dengan nilai hiburan serta romansa ringan yang menarik hati mereka. Untuk tahap ini baik juga dimasukkan dalil-dalil agama yang sudah disederhanakan dalam kalimat sehari-hari. Kedua, sastra islami tingkat lanjut. Karya sastra jenis ini menuntut penghayatan agama pada 
tingkatan 'sufistik'. Artinya, agama sudah dibumikan menjadi nilai-nilai keadaban dan kemanusiaan. Misalnya, ajaran shalat sudah dibumikan menjadi nilai untuk membangun karakter membangun (tidak merusak) dan menyimpang dari adab kemasyarakatan. Ajaran syahadat dibumikan kenjadi nilai kesadaran ketuhanan dan yang tampil sebagai sikap rendah hati, menghargai sesama, tidak memutlakan diri dan sebagainya. Pada tahapan ini sastra islami adalah sastra yang ikut bertanggung jawab kepada perkembangan kehidupan yang beradab. (Tohari, 2016). Dalam konteks penelitian ini, digunakan makna sastra Islami bagian pertama.

\section{Metode Penelitian} $\begin{array}{lll}\text { Jenis } & \begin{array}{c}\text { penelitian ini } \\ \text { kualitatif }\end{array} & \begin{array}{r}\text { dengan } \\ \text { deskriptif }\end{array} \\ \text { melakukan } & \text { penelusuran } & \text { Sistem }\end{array}$ $\begin{array}{lll}\text { melakukan pensuran } & \text { Sistem } \\ \text { Pembinaan } & \text { Kesiswaan berbasis }\end{array}$ Sastra Religius serta melakukan analisis terhadap hal spesifik penyelenggaraan pendidikan melalui pengembangan karakter sastra religius siswa Madrasah Aliyah, serta segala bentuk pembinaan yang dilakukan oleh pihak madrasah yang menopang program pengembangan karya sastra religi (Mulyana, 2008: 201).

Lokasi penelitian dipilih secara purposive dengan memilih Kota Palu (Sulawesi Tengah) sebagai lokus penelitian. Penetapan lokasi didasarkan pada pertimbangan informasi awal yang diperoleh pada peta potensi karya sastra religi peserta workshop Softskills 2016, Balai Litbang Agama Makassar, serta informasi awal tentang pembinaan yang dilakukan di beberapa Madrasah melalui penyampaian guru bahasa Indonesia yang juga mendampingi siswa dalam workshop softskills karya sastra religi siswa Madrasah aliyah se-KTI.

Informan Penelitian terdiri atas informan kunci, informan ahli dan informan biasa. Dalam penelitian ini, informan kunci adalah para guru pengampu bakat minat kesastraan siswa madrasah aliyah, kelompok kreatif berbasis organisasi intra dan ekstra madrasah. Informan ahli adalah Kepala Sekolah, Stakeholder terkait (Dinas Pendidikan maupun Kementerian Agama di tingkat propinsi dan kota), budayawan/sastrawan, dan akademisi. Informan biasa dalam penelitian ini adalah mereka siswa, dan orang tua siswa, serta perangkat madrasah lainnya, di lokasi penelitian.

Dalam penelitian ini, digunakan metode pengumpulan data yang lazim digunakan dalam penelitian kualitatif yaitu observasi dan wawancara. (Cresswell, 1994). Penggunaan metode ini diharapkan dapat mengungkap data lebih dalam dengan menggunakan teknik wawancara mendalam (indepth interview). Penggunaan satu teknik penelitian tentunya tidak dapat menjamin validitas data. Karena itu, teknik wawancara digunakan berpasangan dengan teknik observasi/pengamatan. Teknik ini digunakan untuk melihat bagaimana aktivitas pembinaan sastra religi di sekolah, juga kaitannya dengan kehidupan sehari-hari siswa madrasah. Observasi juga digunakan untuk melihat bagaimana mereka beraktivitas.

Salah satu ciri penelitian kualitatif, yang menjadi instrumen 
adalah peneliti itu sendiri (Sugiyono, 2010: 305). Oleh karena itu, analisis data telah dilakukan sejak penelitian ini berlangsung hingga berakhirnya proses pengumpulan data. Analisis pertama dilakukan pada tingkat reduksi data dengan model analisis deskriptif. Karena proses analisis dilakukan bersamaan dengan proses pengumpulan data, maka kecil kemungkinan terjadinya kekurangan data karena peneliti akan dengan mudah melihat unsur-unsur analisis yang hilang atau tidak dibicarakan dengan informan pada saat penggunaan metode wawancara dan pengamatan berlangsung. Proses analisis tidak hanya berhenti sampai pada penguraian data mentah dalam bentuk deskripsi, tetapi juga dilakukan telaah kritis terhadap data yang dihimpun dengan mendiskusikan dan meneropongnya dari sejumlah pemikiran teoritis berkenaan dengan fenomena pembinaan kesiswaan. Persisnya, analisis dikembangkan dari data yang dikumpulkan selama penelitian, dianalisis pada tingkat reduksi data, disajikan dan dijelaskan secara deskripsi. Artinya bahwa, aktivitas dalam analisis data kualitatif dilakukan secara interaktif dan berlangsung terus menerus sampai tuntas, sehingga datanya sudah jenuh (Miles and Huberman, 1984).

\section{PEMBAHASAN}

\section{Setting Penelitian}

Berdasarkan data dari Seksi Pendidikan Islam Kementerian Agama Kota Palu, menunjukkan bahwa terdapat total 2395 orang Siswa Madrasah Aliyah tahun Pelajaran 2016 - 2017 yang tersebar di 11 Madrasah Aliyah se-Kota Palu. Berikut rekapitulasinya:

\begin{tabular}{|c|c|c|c|c|}
\hline \multirow{2}{*}{ No } & \multirow{2}{*}{ Madrasah } & \multicolumn{2}{|c|}{ Total Siswa } & \multirow{2}{*}{$\mathbf{J m l}$} \\
\hline & & $\mathbf{L}$ & $\mathbf{P}$ & \\
\hline 1 & $\begin{array}{ll}\text { MAN } & 1 \\
\text { Palu } & \end{array}$ & 254 & 461 & 715 \\
\hline 2 & $\begin{array}{l}\text { MAN } 2 \\
\text { Model Palu }\end{array}$ & 332 & 455 & 787 \\
\hline 3 & $\begin{array}{l}\text { MAN } \\
\text { Palu }\end{array}$ & 32 & 30 & 62 \\
\hline 4 & $\begin{array}{l}\text { MAS } \\
\text { Alkhairat } \\
\text { Pusat Palu }\end{array}$ & 155 & 197 & 352 \\
\hline 5 & $\begin{array}{l}\text { MAS Putri } \\
\text { Aisyiyah }\end{array}$ & 0 & 43 & 43 \\
\hline 6 & $\begin{array}{l}\text { MAS DDI } \\
\text { Palu }\end{array}$ & 45 & 27 & 72 \\
\hline 7 & $\begin{array}{l}\text { MAS KT. } \\
\text { Tawaeli }\end{array}$ & 40 & 11 & 51 \\
\hline 8 & $\begin{array}{l}\text { MAS } \\
\text { Muhammad } \\
\text { iyah Nunu }\end{array}$ & 34 & 29 & 63 \\
\hline 9 & $\begin{array}{l}\text { MAS } \\
\text { Alkhairaat } \\
\text { Tondo }\end{array}$ & 60 & 73 & 133 \\
\hline 10 & $\begin{array}{l}\text { MAS Nurul } \\
\text { Falah }\end{array}$ & 33 & 32 & 65 \\
\hline 11 & $\begin{array}{l}\text { MAS Darul } \\
\text { Iman }\end{array}$ & 29 & 23 & 52 \\
\hline \multicolumn{2}{|c|}{ Jumlah Total } & 1014 & 1381 & 2395 \\
\hline
\end{tabular}

Sumber: Seksi Pendidikan Islam Kementerian Agama Kota Palu, 2016

Angka 2395 siswa adalah potensi besar bagi perkembangan sastra religi madrasah aliyah di Kota Palu. Tentunya, jika dilakukan pembinaan yang memadai, mulai dari pencarian bakat, tata kelola pembinaan, serta evaluasi dan outcome. Misal dengan pengadaan even-even khusus yang menghendaki pemilihan sastra religi secara tematik saja, maka potensi pembacaan terhadap bakat dan minat siswa atas pengembangan sastra religi, setidaknya bisa dilacak. Pada medium 2016, gambaran khusus 
tentang minat dan karya siswa madrasah aliyah se-Kota Palu bisa dilihat salah satunya dengan kontribusi naskah sastra religi berupa puisi dan cerpen yang dikirimkan oleh setidaknya 7 orang siswa madrasah mewakili Kota Palu, pada even bertajuk workshop softskills karya sastra religi se-KTI, yang digagas dan dilaksanakan oleh Balai Penelitian dan Pengembangan Agama Makassar, April 2016. Setidaknya, secara kuantitas dan kualitas 7 orang itu tidak/belum merepresentasikan bahwa hanya segitu saja dari 2395 orang siswa madrasah yang berminat untuk mengembangkan sastra religi, namun secara kuantitatif bisa dibaca sebagai 7 orang siswa yang telah memiliki tingkat pengetahuan sastra religi yang sudah cukup mumpuni, sebab memang dalam even itu mempersyaratkan pengajuan karya tulis dalam bentuk cerpen dan puisi. Artinya bahwa mereka yang tidak ikut berpartisipasi, mungkin saja memiliki minat besar, namun belum diwujudkan dalam tulisan. Termasuk beberapa even lainnya yang diagendakan rutin oleh pemerintah setempat, dan atau lomba-lomba bergendre sastra umum lainnya yang dilakukan oleh lembaga/organisasi, dan lain-lain, yang muatannya mengajak para siswa untuk mengartikulasikan jiwa-jiwa kesusastraannya dengan dan atau tanpa iming-iming hadiah/ penghargaan. Belum lagi, penyaluran bakat dan minat sastra yang diwujudkan dalam penugasan sekolah pada mata pelajaran di kelas, khususnya bahasa Indonesia, dan mata pelajaran sastra lainnya di berbagai jurusan sastra.
Fenomena itulah salah satu daya tarik yang kemudian membawa penelitian ini secara lebih khusus melihat sistem pembinaan sastra religi dengan memilih sampel sekolah sebagai objek observasi, setidaknya bisa secara komprehensif menggambarkan penanaman nilainilai religi dalam pengembangan kesusastraan di madrasah Aliyah. Untuk scope Kota Palu, madrasah yang paling cocok untuk melihat dan membaca pelaksanaan pembinaan sastra secara umum adalah MAN 1 Kota Palu, setidaknya beberapa kali, perwakilan siswa MAN 1 Palu mewakili dalam lomba-lomba yang bergendre sastra, serta dalam beberapa perjamuan pejabat penting dari Kementerian Agama Pusat, jika membutuhkan penyambutan dalam bentuk pementasan, tarian selamat datang, dan perayaan isra miraj, maulid, dll, kita sering melibatkan siswa dari MAN Palu, setidaknya dalam beberapa tahun terakhir ini. (Wawancara Asnawir, Seksi Pendidikan Islam Kemenag Kota Palu, 3/11/2016).

Meskipun pengembangan sastra yang secara khusus memilih genre religi pada tingkatan madrasah masih merupakan hal baru, namun melihat skope dan kompetensi kemadrasahannya, maka praktis, menempatkan madrasah sebagai salah satu ujung tombak kekuatan pengembangan sastra religi/sastra Islami, bisa dikedepankan, sebab di dalamnya memang menghendaki pengembangan dan penanaman nilainilai keagamaan yang terintegrasi dalam kurikulumnya. Sehingga, "mengajak" para siswa madrasah untuk menekuni genre religius menjadi cukup berkesinambungan, 
karena sudah inheren dalam kesehariannya. sastra adalah sarana untuk membangun kemampuan berimajinasi (membayangkan sesuatu yang belum ada atau belum dibuat). Sastra juga menjadi sarana untuk mengembangkan kepekaan dalam diri manusia. Kedua hal ini menjadi dasar dan syarat penting untuk membangun kemajuan dan keadaban siswa/masyarakat. Maka sastra harus dihidupkan sehidup-hidupnya. Dari sisi ini kita percaya bahwa kehidupan sekarang yang diliputi berbagai krisis adalah akibat terabaikannya sastra selama 70 tahun terakhir ini. Dalam konteks siswa madrasah, Sastra cukup disajikan dengan bahasa yang mudah, pemikiran yang sederhana sampai menengah dan dengan nilai hiburan serta romansa ringan yang menarik hati mereka. Untuk tahap ini baik juga dimasukkan dalil-dalil agama yang sudah disederhanakan dalam kalimat sehar-hari. Meskipun juga tidak menutup kemungkinan juga sudah ada potensi siswa madrasah yang bakat kesustraannya sudah pada level sastra islami tingkat lanjut yang menuntut penghayatan agama pada tingkatan 'sufistik'. Artinya, agama sudah dibumikan menjadi nilai-nilai keadaban dan kemanusiaan. Misalnya, ajaran shalat sudah dibumikan menjadi nilai untuk membangun karakter membangun (tidak merusak) dan menyimpang dari adab kemasyarakatan. Ajaran syahadat dibumikan menjadi nilai kesadaran ketuhanan dan yang tampil sebagai sikap rendah hati, menghargai sesama, tidak memutlakkan diri dan sebagainya. Pada tahapan ini sastra islami adalah sastra yang ikut bertanggung jawab kepada perkembangan kehidupan yang beradab (Tohari, 2016).

Di Kota Palu sendiri, perhatian pemerintah untuk pengembangan seni budaya dan sastra cukup besar dengan turut diperhatikannya lembaga seni budaya yang ada dan berkembang di masyarakat untuk selanjutnya dilakukan pendataan dan pengesahan berbentuk surat keputusan walikota, untuk dilakukan pembinaan. Bahkan pemerintah kota sangat mengapresiasi segala betuk pertunjukan kesenian dengan memberikan insentif bulanan kepada setiap lembaga seni budaya yang resmi. Hal ini tentunya sangat bergantung pada inisiatif dan minat besar dari walikota dan wakil walikota yang memang memiliki latar belakang berkesinian yang cukup dikenal. Aspek inilah yang menjadi pioner utama tumbuh dan berkembangnya budaya berkesenian, dan bersastra di Kota Palu, sehingga turut memotivasi bertumbuhnya klan-klan seni budaya sampai ke sekolah/ madrasah, sebab eksistensinya dihargai dan diperhatikan. Selanjutnya, sebagai bentuk kajian mendalam, pembahasan berikutnya akan lebih banyak melihat dan sekaligus menjadikannya sebagai sampel percontohan salah satu lembaga seni budaya yang lahir dan berkembang dari madrasah. Dalam hal ini, dipilih objek pengamatan pembinaan sastra religi secara khusus di MAN 1 Kota Palu.

\section{Potensi Sastra Religi MAN 1 Palu}

MAN 1 Kota Palu, sebagai salah satu madrasah aliyah unggulan di Kota Palu, sangat prospektif dalam potensi sastra religinya, selain karena 
ketersediaan kelas bahasa (jurusan bahasa) di setiap tingkatan kelas, pembinaan kesastraan juga telah berjalan sejak lama.

Adalah keterlibatan para siswa dalam segenap organisasi intra madrasah yang membuat pengembangan sastra ikut berjalan serta. Dalam kepengurusan OSIM (Organisasi Siswa Intra Madrasah) misalnya, salah satu program kerja rutin yang diagendakan adalah pembuatan majalah dinding dalam setiap momentum memperingati hari-hari besar nasional dan atau hari-hari besar keagamaan Islam. Majalah Dinding bisa menjadi salah satu wadah dalam mewujudkan ekspresi literasi siswa madrasah yang di dalamnya menghendaki penulisan dan atau pengutipan petuah-petuah bijak, puisi, cerita pendek, dan lainlain yang tentu sangat potensial menunjang berkembangnya jiwajiwa berkesenian dan bersastra.

Pada dasarnya, majalah dinding itu sifatnya sangat tematik, sehingga para siswa yang ingin berkontribusi dalam menuangkan ide-ide kreatifnya sangat tergantung pada tema yang telah ditentukan sesuai dengan momentum sedang memperingati apa. Misalnya, ketika dilakukan pengumpulan karya, ide, dan atau kutipan yang behubungan dengan hari pahlawan, maka mereka tentu akan mencari, membaca, dan menciptakan karya tulis yang berkaitan dengan pahlawan, seperti halnya, ketika sedang memperingati maulid nabi Muhammad, maka segala bentuk ide dan kreatifitas siswa diarahkan dalam rangka memuliakan Nabi Muhammad saw.

Sementara itu, tentang pengarahan secara khusus pada pengembangan sastra religi, siswa MAN 1 Palu tentu memiliki bakat yang sangat besar dalam ranah sastra Islami. Potensi ini tentu tidak lahir begitu saja, namun telah beroleh ruang-ruang pembelajaran dan tempaan yang cukup signifikan dari Madrasah, khususnya oleh para guruguru pembimbing, dan pelibatan mereka dalam berbagai even-even sastra, sebagaimana yang telah dikemukakan sebelumnya. Berikut adalah salah satu sampel karya sastra religi yang dikutip secara langsung dari karya siswi MAN 1 Palu bernama Sulis Zulaika Malistia, yang menurut keterangan kepala madrasah dan guru pembina siswa MAN 1 Palu, merupakan salah satu siswa yang sangat berbakat di bidang sastra, yang dibuktikannya dengan keaktifannya dalam megikuti lombalomba penulisan sastra, seminar sastra, dan keatifannya secara personal dalam lembaga seni budaya, bik intra madrasah maupun ekstra madrasah. Pihak madrasah memberikan keleluasaan kepada siswa dan bahkan memberi dukungan, jika memang dapat memberi nilai plus dalam pengembangan wawasan kesusastraan, latihan menulis, dan kecakapan mental yang dibina berbasis keaktifan secara langsung dalam segala hal yang berbau sastra.

\section{ILHAM}

(Karya: Sulis Zulaika Malistia)

Seringkali aku berlari hingga lelah
Seringkali aku bertahan dalam
kesalahan
Kesalahan yang sulit untuk kusadari
Dan menjeratku ke dalam jaring-
jaring tak bermakna

Seringkali aku berlari hingga lelah Seringkali aku bertahan dalam Dan menjeratku ke dalam jaringjaring tak bermakna 
Entah apa yang aku cari

Seakan tak ada kepuasan dalam batinku

Terkadang aku merasa tak berarti

Namun seringkali...

Naïf mengelabui hati ini

Bergetar hati ini kala tuhan

menyapaku

Dalam sujud malam aku terkikis

Terkikis oleh rasa hina akan dosaku

Tersadarkan oleh sebuah harapan

yang hadir

Apakah ini sosok ilham yang engkau kirimkan Ya Rabb...

Yang akan slalu menuntunku untuk

mendekatkan diri padaMu

Dan selalu berada pada barisan

sujudnya......

Ekspresi religi dalam sastra yang 'diperagakan' siswi MAN 1 Palu ini tentu hanya segelintir dari potensi besar pengembangan sastra religi oleh para generasi emas madrasah. MAN 1 Palu hanyalah satu dari sekian banyak madrasah yang sangat potensial mengembangkan sastra religi di nusantara. Tentu saja, melalui media puisi, siswa telah mampu menerjemahkan ide religiusnya, yang kemudian dituangkan dala susunan kata demi kata yang dirangkai sedemikian rupa sehingga membentuk alunan puisi yang berupa perenungan yang diwujudnyatakan dalam tulisan. Menulis puisi sangat sulit bagi seseorang yang tidak akrab dengan berbagai pertanyaan dan perenungan. Seseorang yang setiap harinya hanya menjadi konsumen informasi yang begitu deras melalui berbagai media elektronik dan menjadi penampungan riuh kota dan pabrikpabrik. Puisi adalah suara-suara jiwa yang tidak setiap orang mendengarnya. Bagi mereka yang suka bisikan, puisi akan sangat mengasyikkan. Puisi ada di dalam sehingga ia perlu dikeluarkan. Umpannya adalah pertanyaan juga bisikan. Kendaraannya adalah perenungan. Dan perwujudannya adalah kata-kata. Menulis puisi sangat sulit bagi seseorang yang bergantung pada yang kasat dan bendawi. Ia ada pada hakikat sesuatu bukan pada tampakan sesuatu. Ia adalah sebuah penyikapan jiwa atas berbagai fenomena. Ia sangat spiritual. Bilapun membahas benda-benda, ia akan mengguar makna dibaliknya. Berarti, puisi akan sangat mengasyikkan bagi yang mencintai segala hal yang bersifat ruhaniah. Karena itu, puisi sangat dekat dengan religiusitas. (Irfan Hidayatullah, 2016: 1). Hal inilah mungkin yang mengilhami puisi ILHAM sebagaimana tertuang di atas, yang dimainkan diekspresikan, dan dituliskan.

Selain puisi, ekspresi religi juga dituangkan dalam cerpen siswa yang di dalamnya menganut nilainilai keislaman. Sesungguhnya, ekspresi literasi para siswa ini telah lama digalakkan melalui semacam penerbitan berbasis penugasan penulisan puisi dan cerpen oleh guru bahasa Indonesia yang selanjutnya dikumpulkan dan dibukukan, sebagai terbitan sekolah sekaligus menjadi koleksi perpustakaan madrasah. Potensi besar ini, pada dasarnya merupakan agenda rutin yang sebaiknya terus dikembangkan untuk memajukan dunia sastra di 
madrasah, bukan hanya sastra umum, tetapi juga sastra religi. Nah ke depan, kita akan menjadikan sastra religi sebagai fokus pengembangan wawasan kesastraan para anak-anak kami di Madrasah, dan hal pertama yang paling mungkin dilakukan adalah, menetapkan tema sastra religi pada peringatan Milad Sanggar Seni Suara Alam MAN 1 Palu (Mas'amah Mufti, 2016). Berikut adalah lampiran sampel puisi dan cerpen religi karya siswi MAN 1 Palu, sebagai manifestasi atas pengembangan sastra religi (baca: sastra Islam), yang kiranya dapat menjadi sumber inspirasi bagi siswa lainnya dalam rangka menumbuhkembangkan nilai-nilai keislaman dalam karya, dan memajukan literasi Islami dalam berbagai aspek. Saya mengembangkan potensi penulisan puisi dan cerpen religi ini sejak lama, dan kemudian mengapliksikan dalam pengajuan cerpen dan puisi itu pada workshop softskills yang diagendakan oleh Balai Litbang Agama Makassar (Sulis Zilaika Malistia, 2016).

Sesungguhnya, setiap karya sastra bernuansa religi yang dilahirkan oleh siswa madrasah, adalah wujud dari penghayatan situasional madrasah yang di dalamnya sudah inklud iklim keislaman yang lebur dalam lingkungan dan tujuan madrasah itu sendiri. Semakin mereka (para siswa) menyelami dan mengalami setiap aktifitas, rutinitas, dan identitas kemadrasahannya, semakin luas samudera sastra yang bisa dicipta dan diartikulasinnya. Hal ini senada dengan statement sarat makna ala
Irfan Hidayatullah yang mengatakan bahwa: Menulis puisi (dan sastra lainnya, pen.) sangatlah sulit bagi siapa saja yang meninggalkan ruang terdekat yang menguasai dan dikuasainya. Ruang yang membesarkannya pada setiap detik peristiwa, ruang yang setiap aromanya ia pahami sekali, ruang yang hanya dia sendiri yang memilikinya. Karena itu, puisi akan muncul dari pengalaman yang sangat individual dan sakral. Keindonesiaan, kemakassaran, kesundaan, kekampungan, kekotaan, kerumahan, kekamaran, dan kedirian kita adalah semacam lokalitas yang sangat mahal harganya. Dari sana metafora-metafora yang dibuat akan asli dan segar takada bandingannya. Engkau akan menjadi engkau karena lokalitasmu yang sangat berbeda bahkan dengan saudara kembarmu sekalipun. Pada akhirnya, seseorang telah dilahirkan dengan potensi kepuitisan dalam dirinya. Namun, tidak setiap orang mampu dan harus mampu menuliskannya. Bagi yang tertarik dan terpanggil untuk menuliskannya hanya satu cara yang harus ditempuh: ikuti segala alur yang sudah dibicarakan di atas dan akhiri dengan menuliskannya. Akhiri dengan menuliskannya. Akhiri dengan menuliskannya. Berlatihlah pada setiap jejak ruang hidupmu dan ungkapkan segala hikmah yang telah diikat. Jadikan ia sebagai salah satu cara untuk mendekati-Nya. (Hidayatullah, 2016).

\section{Pembinaan Sastra Religi Siswa MAN 1 Palu}

Kajian secara komprehensif pelaksanaan pembinaan sastra religi bagi siswa di MAN 1 Palu, harus 
terlebih dahulu dikaitkan dengan pelaksanaan pembinaan seni dan kesusastraan secara lebih luas/umum. Sebagaimana telah disinggung sebelumnya, bahwa pelaksanaan pembinaan sastra dan kesenian di MAN 1 Palu telah berlangsung sangat lama, eksistensi itu menjadi sangat mendukung nilai-nilai dan peminatan para siswa untuk mencintai seni dan kesusatraan. Adalah seorang guru damping bernama Mas'amah Amin Syam menjadi salah satu tokoh yang sangat penting yang dimiliki oleh MAN 1 Palu dalam rangka meningkatkan, dan memajukan bakat dan peminatan siswa-siswi mengejewantahkan jiwajiwa seninya. Karakter dan kesungguhan yang dimiliki oleh guru damping adalh motivator bagi siswa. Pembawaan yang sangat ceria, menjadi yang utama dibutuhkan oleh peserta didik jika inner capacity-nya hendak dikembangkan. Seni dan sastra adalah dua hal yang tidak dimiliki oleh semua siswa. Sehingga, mengajak mereka untuk menulis dan berkesenian adalah sebuah problem, jika tidak disampaikan dengan bijaksana dan penuh keramahan. Itulah yang dilakukan oleh Ibu Mas'amah Amin yang tidak hanya memosisikan dirinya sebagai guru di kelas, tetapi juga sekaligus menjadi orang tua bagi para siswa. Keramahan, kasih sayang, dan pembinaan berbasis emosioal juga dilakukannya, demi menjalin keakraban dengan para siswa.

Justru dengan jarak yang sedemikian tipis itu (atau mungkin bisa dikatakan tidak berjarak lagi), antara guru dan siswa, maka hampir dipastikan, bahwa transfer kasih sayang, transfer emosional, transfer bimbingan, pengetahuan, bahkan bakat dapat terjalin. Siswa yang awalnya tidak berbakat seni dan sastra menjadi tertarik dan berminat menekuninya karena memiliki sosok bina damping yang sangat kharismatik dan mengayomi. Mereka memanggilnya bunda, sebuah panggilan akrab layaknya anak kepada orang tuanya. Bunda adalah sosok panutan kami di madrasah, keberadaannya membuat kami sangat bersemangat dalam kegiatan apa saja, khususnya bidang kesenian dan sastra. Beliau tidak hanya mengajarkan, tetapi sekaligus memberi contoh. Kami banyak terinspirasi dari karya-karya bunda baik yang telah dibukukan maupun yang banyak dimuat di koran-koran. Dan itulah yang menjadi pelecut motivasi bagi kami generasi muda, untuk turut andil dalam menggali bakat dan minat kami dalam menulis dan berkesenian, atau setidaknya dapat mengikuti jejak bunda. (Wawancara Aldy, 02/12/2016).

Terlihat bahwa pembinaan terlibat menjadi sesuatu yang menjadi titik balik pengembangan sastra di MAN 1 Palu, yang di dalamnya mengalir asa postif pengembangan genre lainnya. Hal lain, yang juga turut andil dalam proses pembinaan sastra religi adalah tersedianya wadah bagi para siswa untuk mengembangkan bakat dan minatnya dalam bidang seni dan sastra yang tterwujud dalam lembaga intra madrasah bernama Bengkel Seni Suara Alam, MAN 1 Palu. Bengkel Seni Suara Alam (BSSA) terbentuk tanggal 21 Desember 1999 melalui hasil musyawarah penggiat seni siswa MAN 1 Palu oleh Sakinatul Kulun, dan Nafian Arifin. 
Anggota pertama masih belasan orang. Namun kini dalam perkembangannya di perjalanan usianya yang sudah kurang lebih 13 tahun, anggotanya sudah terdata sekitar 156 orang, dengan pembagian bidang seni musik, tari, peran, sastra, dan kaligrafi. Nama "Suara Alam" mengandung filosofi bahwa Allah dalam menciptakan alam ini untuk bahan inspirasi dan imajinasi. Alumni BSSA MAN 1 Palu, kini menghadirkan semacam media sosialisasi dan komunikasi berbasis dunia maya tujuannya selain untuk sarana silaturahmi, juga sekaligus sharing agenda dan rutinitas, bahkan arena konsultasi antara junior dan senior. (Mas'amah Amin, Pembina BSSA MAN 1 Palu 04/11/2016)

Melalui wadah Bengkel Seni Suara Alam inilah, pengembangan seni dan sastra di MAN 1 Palu dikembangkan. Dengan pembagian bidang seni musik, tari, peran, sastra, dan kaligrafi membuat peluang pengembangan sastra religi menjadi sangat besar. Ruang yang dimungkinkan dapat dikembangkan setidaknya dalam dua bidang yakni Sastra dan Kaligrafi, meskipun tidak menutup kemungkinan bahwa religiusitas juga dapat dikelola melalui musik, tari dan teater. Mereka yang aktif dan mengambil bagian dalam kenaggotaan Bengkel Seni Suara Alam, adalah juga yang banyak mengambil peran dalam dinamika dan pergulatan kegiatan yang melibatkan siswa pada agenda madrasah. Tak jarang mereka juga turut diundang dalam kegiatankegiatan pementasan seni di luar madrasah. Terlebih Bengkel Seni Suara Alam adalah salah satu dari beberapa lembaga seni budaya yang diakui oleh pemerintah Kota Palu, sehingga jika ada event-event yang mempertemukan para pelaku seni dan pemerhati budaya di Kota Palu, mereka selalu diundang meski hanya sekadar mengisi acara dengan satu atau dua penampilan.

Kita sedapat mungkin akan selalu menghadiri segala jenis event seni budaya yang diadakan di Kota Palu, bahkan BSSA kini menjadi salah satu lembaga seni budaya bentukan Madrasah yang dikenal di Palu, sejajar dengan lembaga seni budaya bentukan lembaga independen. BSSA selalu diundang, bila ada lembaga seni budaya lainnya yang melakukan hajatan, apakah itu milad, maupun kegiatankegiatan rutin dan insidentil lain yang mereka lakukan, disana kami diharuskan menampilkan sesuatu untuk menghibur para peserta. Kehadiran kami di even tersebut adalah kolaborasi antara anggota muda, para senior (bina damping), dan bunda (Masmah Amin) sendiri sebagai pembina. (Aldy, Bina Damping BSSA, Sekaligus Ketua Sanggar Seni Lauro). Bangunan komunikasi intra dan antar lembaga menjadi kunci eksistensi BSSA MAN 1 Palu hingga menjadi salah satu lembaga seni budaya yang 'diperhitungkan' di Kota Palu, dan menjadi satu-satunya lembaga seni bentukan madrasah yang mendapat pengakuan pemerintah setempat.

Hal lain yang menjadi sorotan dalam pembinaan sastra religi, adalah adanya Sanggar Seni Lauro yang dibentuk oleh para alumni BSSA MAN 1 Palu yang telah menyelesaikan studinya di bangku Madrasah Aliyah. Karena 
kecintaannya pada seni budaya dan kesusatraan, membuat mereka kemudian membentuk wadah pasca purnabakti di BSSA, yang mereka sebut sebagai Sanggar Seni Lauro. Keanggotaan SSL ini adalah mereka para alumni MAN 1 Palu yang sebelumnya menjadi anggota pada BSSA. Sehingga kaderisasi tetap berjalan, dan kebertahanan dalam berkesenian dan berkebudayaan tetap dilanjutkan dan dikembangkan sedemikian rupa. Bahkan mereka para 'senior' di SSL, secara otomatis menjadi bina damping bagi adikadiknya di BSSA. Tak jarang mereka tampil bersama dalam evem-even seni budaya di kota Palu. Atau setidaknya mengarahkan dan mendiskusikan segala bentuk karya seni dan sastra adik-adiknya jika diantara mereka di BSSA ada yang mengikuti lomba dan atau event tertentu yang bergenre sastra dan kesenian.

Seni dalam pribadi manusia sejak ia dilahirkan sudah ada jiwa seni di dalamnya, walaupun kadar yg dimiliki berbeda-beda. Seni adalah akar kebudayaan, maka harus dilestarikan dan itu tugas generasi muda khususnya pelajar. Seni berhubungan dengan bakat, dan bakat itu sendiri perlu dipacu dari dalam diri kita masing-masing. Karena kalau kita menyukai seni, maka kita bicara hati nurani, akalbudi, ukuran karakter, dan semangat yang tak akan putus dalam meperjuangkan sebuah arti. Berkesenian pada dasarnya merupakan kebutuhan mutlak yang hakiki bagi setiap pelajar dalam meraih cita-citanya melalui minat dan bakat, maka diharapkan dapat memperhalus ahlak, dan budi pekerti pelajar dalam rangka mengenal budaya bangsa, serta mempertinggi rasa toleransi. Harapan umum: membina generasi muda Islam khususnya di kalangan usia skolah. Maka perlu menyelenggarakan kegiatan yang bermanfaat bagi pertumbuhan dan pengembangan kualitas siswa dalam hal berkesenian, berekspresi, berkarya, dan menjaring minat dan bakat agar menjadi generasi yang beraqidah Islamiah yang mantap, berilmu, dan berakhlak mulia lewat kesenian. Harapan khusus: BSSA mampu memberikan segores arti \& setumpuk harapan bagi masa depan MAN 1 Palu, dan segala program kerjanya: Dengan menciptakan terminal kreatifitas minat dan bakat siswa, karena melalui kesenian dapat menggugah orang, ikut memikirkan masalah yang ada di sekeliling kita, dari apa yang dilihatnya, didengarnya dan yang dirasakannya. (Mas'amah Amin, 04/11/2016).

\section{PENUTUP}

Pengembangan sastra religi dan pembinaannya yang berbasis sekolah/madrasah, sesungguhnya merupakan alur utama perluasan citarasa literasi generasi muda bangsa, khususnya yang memuat aspek-aspek religiusitas. Pembinaan ini sekaligus juga merupakan alat filter dari beragam genre susastra yang berada 'di luar jalur-jalur normatif', diharapkan sebagai bagian integral pembentukan akhlak remaja. Apa yang dilakukan dan telah dikembangkan di Madrasah Aliyah Negeri 1 Palu Sulawesi Tengah, hanyalah salah satu contoh model pengembangan sastra religi yang sifatnya terintegrasi antara para siswa 
dengan penyaluran bakatnya, serta guru pembina dengan dorongan serta semangat mengayomi yang mengakar dan mencerahkan. Ketersediaan wadah, serta dukungan pihak madrasah yang boleh dikatakan sangat mensupport kegiatan-kegiatan pengembangan sastra bisa dijadikan sebagai model atau setidaknya jadi inspirasi madrasah lainnya untuk juga ikut serta dalam memasyarakatkan literasi berbasis religi di kalangan generasi muda.

Penelitian ini juga menemukan kontekstualiasasi dan perluasan makna sastra religi yang tidak hanya berbasis Qurani, tetapi juga menghendaki eksplorasi mendalam tentang asimilasi aktif antara sastra dalam gendre lokalitas (baca: sastra daerah) diintegrasikan dengan sastra Islami. Hal ini menunjukkan betapa dinamisnya perkembangan sastra yang ternyata juga sudah menyasar dan tercerap oleh para siswa madrasah, yang diharapkan sebagai pioner pengembangan sastra religi ke depan.

\section{DAFTAR PUSTAKA}

Abdurrahman, Bintu al-Syati' Dr. Aisyah. 1992. Qiyamun Jadidah lil-Adab al-Araby. Kairo: Dar al-Maarif.

al Mozayyen. Ala. Seminar Sastra Islam Internasional, 15 Maret 2011, Institut Negeri Jakarta.

Anonoim 2009. "Manajemen Pembinaan Kesiswaan". Warna Dunia. 29 Oktober 2009. (sumber:: http://warnadunia.com/manaje men-pembinaan-kesiswaan).

Arini, Esti Gusti. 2012. Pembinaan Siswa Berbakat dan Berprestasi Di SMA Negeri 1 Semarang. Jurnal Varia Pendidikan, vol. 24. No. 2, desember 2012.

Badudu JS. 2002. Kamus Lengkap Bahasa Indonesia. Balai Pustaka, Jakarta

Chaniago, Anto. 2010. "Administrasi Kurikulum dan Kesiswaan". (sumber:

wordpress.com/2010/05/babxi.doc).

Cresswell, John W. 1994. Research Design, Qualitative and Quantitative Approaches. California: Thousand Oaks.

Departemen Pendidikan Nasional. 2008. Kamus Besar Bahasa Indonesia (Pusat Bahasa) Edisi Keempat. Jakarta: PT. Gramedia Pustaka Utama.

Depdiknas. 2008. Peraturan Menteri Pendidikan Nasional Republik Indonesia Nomor 39 Tahun 2008 Tentang Pembinaan Kesiswaan. Jakarta: Biro Hukum dan Organisasi Departemen Pendidikan Nasional.

Firdaus, Fattah. 2009. "Model Sistem Kesiswaan Berdasarkan Desain Sistem Instruksional ADDIE". (sumber: www.teknologipembelajaran.co.cc).

Hadi W.M., Abdul. 1985. Sastra Sufi Sebuah Antologi. Jakarta: Pustaka Firdaus 
Hidayatullah, M. Irfan. 2016. Mari Berpuisi pada Setiap Jejak Ruang Hidup Ini. Disampaikan pada acara Program Pengembangan Softskill Karya Sastra Religi Siswa MA di Kawasan Timur Indonesia, Makassar, 23 April 2016

Kailani, Najib. 1985. Rihlati Ma'a al-Adab al-Islamy. Beirut: Muassasah al-Risalah.

King. 2009. "Acceleration". (sumber: http://www.hoagiesgifted.org).

Majalah Horison, 7/1984.

Milles, M.B. and Huberman, M.A. 1984. Qualitative Data Analysis. London: Sage Publication

Mulyana, Deddy. 2008. Metodologi Penelitian Kualitatif (paradigma Baru Ilmu Komunikasi dan Ilmu Sosial Lainnya). Bandung: PT. Remaja Rosdakarya.

Mulyasa, E. 2008. Standar Kompetensi dan Guru Sertifikasi. Bandung: PT. Remaja Rosda Karya.

Peraturan Menteri Pendidikan Nasional (Permendiknas), Nomor 39 Tahun 2008

Said Hawwa. 2004. Al Islam. Gema Insani Press, Jakarta.

Senjaya, Wina. 2008. Strategi Pembelajaran; Berorientasi Standar Proses Pendidikan. Jakarta: Kencana Prenada Media Group.

Siswanti, Parlina Susi. 2012. Pengaruh Karya Sastra Puisi Anak Terhadap Perkembangan Karakter Siswa Kelas $3 a$ di
SDN Babakan 04, Pendidikan Guru Sekolah Dasar Fakultas Keguruan dan Ilmu Pendidikan Universitas Muhammadiyah Prof. Dr. Hamka, Jakarta.

Sugiyono. 2010. Metode Penelitian Pendidikan (Pendekatan Kualitatif, Kuantitatif, dan $R \& D)$. Bandung: Alfabeta.

Sukmadinata, Nana Syaodih. 2005. Landasan Psikologi Proses Pendidikan. Bandung: Remaja Rosdakarya.

Suryosubroto, B. 2009. Manajemen Pendidikan di Sekolah. Jakarta: Rineka Cipta.

Teeuw. 1984.Sastra dan Ilmu Sastra: Pengantar Teori Sastra. Jakarta: Pustaka Jaya.

Tohari, Ahmad. 1998. Sastra dan Budaya Islam Nusantara (Dialektika Antarsistem Nilai). Yogyakarta: SMF Adab IAIN Sunan Kalijaga. . 2016. Membangun Karakter Religius Melalui Karya Sastra. Disampaikan dalam Workshop Softskills Karya Sastra Religi Siswa Madrasah Aliyah SeKTI. Balai Litbang Agama Makassar, 22-25 April 2016. 